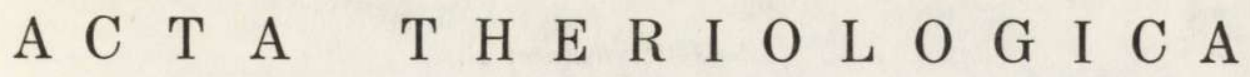

VOL. 19, 19: 283-289.

BIAEOWIEŻA

September, 1974

BISONIANA LV

Zofia GE BCZYNSKA, Jan KOW A L CZYK, Małgorzata KRASINSKA \& Aleksandra ZIO£ECKA

\section{A Comparison of the Digestibility of Nutrients by European Bison and Cattle*}

[With 2 Tables]

\begin{abstract}
Apparent digestibility coefficients of nutrients and energy of the ration were determined in 2 European bisons deriving from a free ranging herd in the Białowieża Forest, and in 2 Black and White Lowland bulls. The diet consisted of meadow hay $(70 \%)$ and ground barley $(30 \%)$ with the addition of $\mathrm{Cr}_{2} \mathrm{O}_{3}$ as the indicator of digestibility. The experiment was continued for 30 days, faeces being collected for 10 days in this period. The content of crude protein and crude fibre in the dry matter of the feed amounted to 11.9 and $22.3 \%$, respectively. The energy value of $1 \mathrm{~kg}$ of the dry matter was $4347 \mathrm{kcal}$ of gross energy. The apparent digestibility coefficients of the nutrients for bisons were higher than for cattle, except cellulose, soluble and readily hydrolysed carbohydrates. The higher coefficients include crude protein $(37 \%)$, ether extract $(45 \%)$, lignin $(198 \%)$ and ash $(76 \%)$. These results indicate a better feed utilization as expressed by the digestibility of nutrients and energy, by European bisons than by cattle.
\end{abstract}

\section{INTRODUCTION}

In relation to the investigations on the role of the European bison in forest ecosystems of the Białowieża Forest it is essential to determine not only the specific composition and amount of consumed food but also the extent of its utilization by the animal organism.

Studies on the species composition and food preference of free ranging herd of European bisons have been hitherto carried out by B a škirov, 1939; Zablockaja, 1957; Borowski, Krasiński \& Miłkowski, 1967; Koročkina, 1966; 1969a, b; Borowski \& Kossak, 1972. The selectivity and food requirements of the bison were described

* Praca została wykonana w ramach problemu węzłowego 09.1.7. koordynowanego przez Instytut Ekologii PAN. 
in an earlier paper ( $G$ ę bczyńska \& Krasińska, 1972). On the other hand, data concerning digestibility and food utilization in this species are almost totally lacking. The only available report is that published by $\mathrm{Szaniawski}$ (1959). Elucidation of this problem is an essential link in further studies on the estimation of the energy balance of bisons living in the Białowieża Forest.

The aim of present study was to compare the digestibility of nutrients and energy of a ration in European bisons and in domestic cattle.

\section{MATERIAL AND METHOD}

The experiment on 2 European bisons was carried out in the Mammals Research Institute at Białowieża. The animals deriving from a free ranging herd were: Kalif (Pedegree No. 2753, live weight $200 \mathrm{~kg}, 2$ years old) and Karat (Pedegree No. 2752 , live weight $300 \mathrm{~kg}, 3$ years old). Parallel comparative experiments on two Black and White Lowland bulls weighing $240 \mathrm{~kg}$, aged approximately 8 months, were carried out in the Institute of Animal Physiology and Nutrition at Jablonna.

Specific conditions of life of European bisons make difficult the employment of classical methods of determination of nutritive value and utilization of consumed feedstuff. For this reason the indicator method was employed in the experiment.

The food ration of all animals consisted of meadow hay $(70 \%)$ and ground barley $(30 \%)$ with the addition of $\mathrm{Cr}_{2} \mathrm{O}_{3}$. The ground barley was thoroughly mixed with the indicator to ensure a uniform distribution of chromic oxide in the feed, and pelleted.

The captured European bisons were placed in an experimental forest reserve, $10 \mathrm{ha}$ in area. For the period of the proper experiment they were transferred to enclosures, $135 \mathrm{~m}^{2}$ in area, with the run covered with concrete. The daily ration was supplied in two equal portions at $8^{00}$ and $16^{\circ 0}$, but on account of body weight differences Kalif obtained jointly $6 \mathrm{~kg}$ of feed and Karat $7 \mathrm{~kg}$. After a twenty-day initial period, in which the final daily ration was established, the collection of faeces was carried out for 10 days.

Samples of faeces were taken from each defaction. Also samples of feed were taken for chemical analysis during the whole collection period. Water was given aiways ad libitum.

The bulls were given the experimental ration for 29 days before the collection period. Similarly to bisons they obtained feed twice daily in the amount of $7 \mathrm{~kg}$. Before and during faeces collection the ration was reduced to $5 \mathrm{~kg}$ in order to ensure complete consumption. Drinking water was always available. During the collection period the animals were maintained in metabolic cages and faeces were collected for 4 consecutive days.

The content of nutrients in the feed and faeces was estimated by conventional methods. In addition, the following components were determined: soluble carbohydrate, readily hydrolysed carbohydrates, cellulose and lignin according to the metods recommended by the Oskar Kellner Institute in Rostock ( $\mathrm{H}$ of $\mathrm{fmann}$ \& $\mathrm{Neh}-$ ring, 1969), pentosans and hemicellulose from the difference between the sum of carbohydrate components and determined fractions, and chromium oxide according to Struszyńs ki (1954). 
The apparent digestibility coefficients were estimated by means of the indicator method with $\mathrm{Cr}_{2} \mathrm{O}_{3}$. The digestible energy of the ration was calculated from the difference between the gross energy of the feed and faeces using the coefficients given by Nehring et al. (1970). The amount of faeces excreted by bisons was calculated from the amount of the indicator assuming $100 \%$ recovery of chromium oxide given with the feed.

\section{RESULTS}

The results of chemical analyses of feed and faeces are given in Table 1. The contents of crude protein and fibre in the dry matter of feed amounted to 11.9 and $22.3 \%$, respectively, and the energy value of $1 \mathrm{~kg}$ of feed corresponded to $4347 \mathrm{kcal}$ gross energy.

The animals readily consumed all supplied feed leaving no remnants.

The digestibility coefficients of all nutrients, except cellulose, soluble carbohydrate and readily hydrolysed carbohyrates, were higher in bisons than in cattle (Table 2). The differences were greatest for crude protein $(37 \%)$, ether extract $(45 \%)$, lignin $(198 \%)$ and ash $(76 \%)$.

\section{DISCUSSION}

The results obtained seem to indicate a better utilization of feed, in terms of the digestibility of nutrients and energy, by bisons than by cattle. The considerable difference in the digestion of lignin between the two compared species of ruminants indicates a better ability to digest this component in bisons. In their natural environment bisons consume feed rich in lignin and thus their digestive system may be better adapted than that of domestic cattle. However, taking into consideration the limited number of animals in the experiment, their individual variation and the relatively large error involved in lignin determination it is difficult to establish the real degree of better utilization of this component by bisons. The problem requires further studies. The differences in the digestability of ash may be due to the fact that bisons staying in the enclosures could, apart from feed, take up some additional mineral components by licking them up from the concrete floor of the run.

Most of the studies concerning digestibility of nutrients in free living ruminants were carried out on Cervidae (deer, elk, reindeer, roe-deer). From the investigations carried out on European bisons only the results of $\mathrm{Sz}$ a niaw ski (1959) are known. The author compared a half-year-old bison calf and a domestic young bull of the same age. In contrast to our results S z a niaw ski (1965) found that the digestibility of crude and true protein, fibre and nitrogen-free extractives in the bull was higher than in the bison. It is possible that in the young bison the digestive system was not yet properly developed since it is known that bisons 

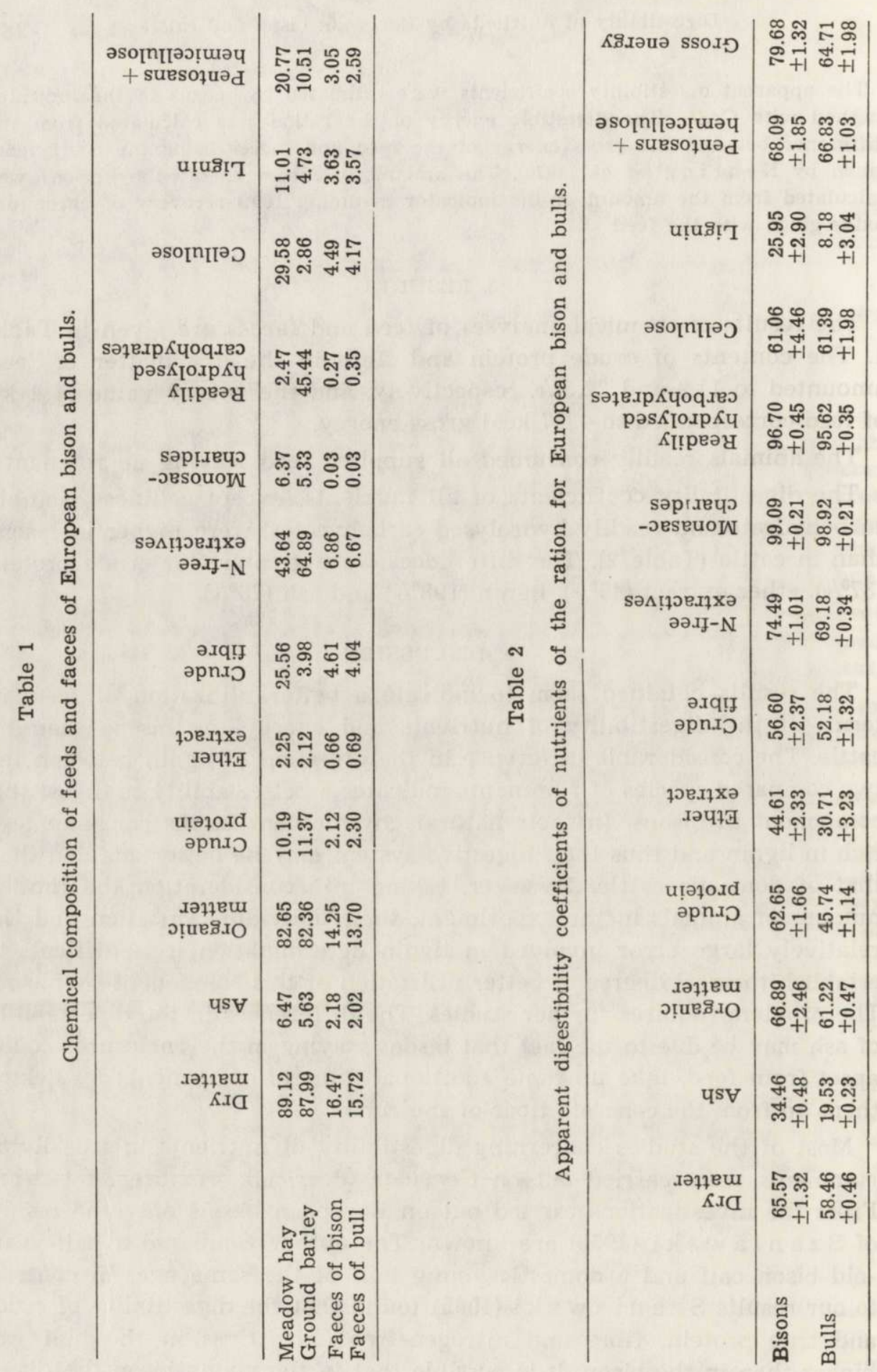
at this age still suckle their dams (W r ó b lew ski, 1927), while a half-year-old bull utilizes feed as well as adult cattle $(\mathrm{Zi}$ ołe cka, 1969; Church, 1971).

The coefficients of digestibility of the dry matter (65.4) and organic matter (66.7) obtained in our experiments for European bisons are similar to those reported by $\mathrm{Rice} \& \mathrm{Church}$ (1971) for the deer. On the other hand, the digestibility of individual components was in the experiments of these authors either higher (protein, ether extract), or lower (lignin, hemicellulose, cellulose) in comparison with European bison. The coefficients of digestibility of dry matter, protein and cellulose in deer in the experiments of $\mathrm{M}$ a lo $\mathrm{y}$ \& $\mathrm{K}$ e $\mathrm{y}$ (1971), varied depending on the quality of feed in the range of $53-62,42-61$ and $52-64$, respectively.

However, it is difficult to compare and generalize these data since the experiments were carried out on different ruminant species, under different conditions and using different feed.

Soluble carbohydrate and readily hydrolysed carbohydrates are almost completely fermented already in the rumen ( $\mathrm{H}$ o b s o $\mathrm{n}, 1969$; $\mathrm{K}$ ow a lczyk, Ramirez \& Geerken, 1969) hence no difference in their digestibility was observed between cattle and bisons. The small amount of soluble carbohydrate and readily hydrolysed carbohydrates excreted with faeces might come from undigested microorganisms and glycoproteins.

The results obtained in our experiments confirm a widespread opinion that free living animals digest and utilize feed more efficiently than do domestic animals ( $\mathrm{Church}$ et al., 1972). The differences may be caused by different anatomical structure and physiological properties of the intestinal tract in various ruminant species ( $\mathrm{T}$ o m me et al., 1953; Sablina, 1970; Prins \& Geelen, 1971; Szaniawski 1973).

In the light of our experiment the problem of digestibility of feed in the European bison seems to be interesting and should be continued with the use of natural feed consumed by bisons in the Białowieża Forest in various seasons of the year.

A better understanding of this problem may have practical application in proper breeding of this species as free ranging herds, as well as in a more rational economy of feeding fields.

\section{REFERENCES}

1. B a šk ir o v I., 1939: Kavkazkij zubr. Glav. Upravl. po Zap., Zoopark. i Zoosad. S.N.K. RSFSR: 1-72. Moskva.

2. Borowski S. \& Kossak S., 1972: The natural food preferences of the European bison in season free of snow cover. Acta theriol., 17, 13: 151-169. 
3. Borowski S., Krasiński Z. \& Miłkowski L., 1967: Food and role of the European bison in forest ecosystems. Acta theriol., 12, 25: 367-376.

4. Church D. C., 1971: Digestive physiology and nutrition of ruminants. Digestive physiology. Ed. D. C. Church: 27-38.

5. Gębczyńska Z. \& Krasińska M., 1972: Food preferences and requirements of the European bison. Acta theriol., 17, 10: 105-117.

6. Hobs on P. M., 1969: Microbiology of digestion in ruminants and its nutritional significance. [In: "Nutritional animals of agricultural importance $]$ ]. Part 1: 59-85. Ed. D. Cuthbertson. Pergamon Press, Oxford.

7. Hoff mann B. \& Nehring K., 1969: Untersuchungen zur Weiterentwicklung der Futtermittelanalyse. Mitt. 2. Die Bestimmung der Kohlenhydrate in den Futtermitteln. Arch. Tierenähr., 19, 9: 651-670.

8. Kor o čkina L. N., 1966: K voprosu o značenii drevesnoj rastitelnosti v pitani zubrov Belovežskoj Pušči. Vesci AN BSSR, 1: 106-111.

9. Kor o čk in a L. N., 1969a: Vidovoj sostav lesnoj travianistoj rastitelnosti v pitanii zubrov Belovežskoj Pušči. Belovežskaja Pušča, Issledovanija, 3: 204-221.

10. K o r o čk in a L. N., 1969b: Drevesnaja rastitelnost v pitani zubrov Belovežskoj Pušči. Belovežskaja Pušča, Issledovanija, 3: 120-126.

11. Kowalczyk J., Ramirez A. \& Geerken C. M., 1969: Studies on composition and flow of duodenal contens in cattle feed diets high in molasses and urea. Rev. cub. Scienc. Agric., 3: 221-226.

12. M a 1 o i y G.M.O. \& K a y R.N.B., 1971: A comparison of digestion in red deer and sheep under controlled conditions. Quart. J. exp. Physiol., 56: 257-266.

13. Nehring K., B eyer M. \& $\mathrm{H}$ of $\mathrm{fm}$ an $\mathrm{n}$ B., 1970: Futtermitteltabellenwerk. DLV. Berlin.

14. Ørskov E. R., M y es R. W. \& M a n n S. O., 1972: Postruminal digestion of sucrose in sheep. Br. J. Nutr., 28: 425-432.

15. Prins R. A. \& Geelen M. J. H., 1971: Rumen characteristics of red deer, fallow deer and roe deer. J. Wildl. Manage., 35, 4: 673-680.

16. Rice P. \& Church D. C., 1971: Unpublished data. From Digestive Physiology and Nutrition Ruminants. Vol. 3. Practical Nutrition. By D. C. Church (1972). O.S.U. Corvallis.

17. Sa blina T. B., 1970: Evolucija piščevaritelnoj sistemy olenej. Izd. "Nauka": 1-247. Moskva.

18. Struszyń ski M., 1954: Analiza ilościowa i techniczna. Państw. Wyd. Techn., 2: 192-193. Warszawa.

19. Szaniawski A., 1959: Comparison of digestibility of feedingstuffs with different protein ratios for calves of domestic cattle and of bison, Bison bonasus (L.). Acta theriol., 3, 13: 318-319.

20. Szaniawski A., 1973: Proportions of the alimentary tract in deer. Acta theriol., 18, 18: 343-350.

21. Tomme M. F., Ksantopuło O. J. \& Siementovskaja N. M, 1953: Perevarimost' kormov. Gosud. Izd. Sel.-hos. Lit.: 1-218. Moskva.

22. Wróblewski T., 1927: Żubr Puszczy Białowieskiej. Wyd. Polskie: 1-232 + XVI. Poznań.

23. Verme L. J. \& Ullre y D. E., 1972: Feeding and nutrition of deer. [In: "Digestive physiology and nutrition of ruminants«, ed. D. C. Church]. 3, 275-291. 
24. Zablockaja L. V., 1957: Pitanije i estestvennaja korma zubrov. Trudy prioksko-terras. gos. Zap., 1: 66-143.

25. Zi ołecka A., 1969: Badania nad oznaczaniem strawności u przeżuwaczy. Rocz. Nauk rol., D, 127: 1-153.

Accepted, February 23, 1974.

Mammals Research Institute, Polish Academy of Sciences, 17-230 Białowieża, Poland.

Institute of Animal Physiology and Nutrition, and Polish Academy of Sciences, 05-110, Jabłonna n. Warszawa.

\section{Zofia GEBCZYŃSKA, Jan KOWALCZYK, Małgorzata KRASIŃSKA i Aleksandra} ZIOEECKA

\section{STRAWNOSC SK£ADNIKOW POKARMOWYCH W PASZY U ŻUBROW I BYDEA}

\section{Streszczenie}

Określono współczynniki strawności składników pokarmowych oraz energię dawki pokarmowej stosowanej u 2 żubrów w wieku 2 i 3 lata odpowiednio, pochodzących $\mathrm{z}$ wolnego stada $\mathrm{z}$ Puszczy Białowieskiej oraz u 2 buhajów rasy nizinnej czarnobiałej, w wieku 8 miesięcy.

Dawka pokarmowa składała się z siana ląkowego $(70 \%)$ i śruty jęczmiennej $(30 \%)$ z dodatkiem $\mathrm{Cr}_{2} \mathrm{O}_{3}$ użytego jako wskaźnik do oznaczenia strawności. Doświadczenie trwało $30 \mathrm{dni}$, w tym okres kolekcji kału 10 dni. Wyniki analiz chemicznych paszy i kału zawarte są w Tabeli 1. Zawartość białka ogólnego i włókna w suchej masie paszy wynosiła 11,9 i $22,3 \%$ odpowiednio, a wartość energetyczna $1 \mathrm{~kg}$ suchej masy odpowiadała $4347 \mathrm{kcal}$ energii brutto.

Współczynniki strawności składników pokarmowych z wyjątkiem celulozy oraz cukrów prostych i węglowodanów łatwo hydrolizujących były wyższe u żubrów niż u bydła domowego (Tabela 2). Największe różnice wystąpiły w strawności białka ogólnego $(37 \%)$, ekstraktu eterowego $(45 \%)$, ligniny $(198 \%)$ oraz popiołu $(76 \%)$. Uzyskane wyniki wskazują na lepsze wykorzystanie pasz wyrażone strawnością jej składników i energii przez żubry niż przez bydło domowe. 